\title{
A Review of Use of GiS for the Evaluation of Heavy Metal and Water Quality Parameters in the Canal do Cunha Watershed and West of the Guanabara Bay, Rio de Janeiro (BraziL)
}

\section{RENATA COURA BORGES ${ }^{1 *}$ AND VANESSA GODOY CALDAS ${ }^{2}$}

\author{
1 Instituto Nacional de Tecnologia, Avenida Venezuela, 82 - Saúde, 20081-312, Rio de Janeiro - RJ, Brazil. renatacouraborges@hotmail.com \\ 2 Instituto de Engenharia Nuclear, Rua Hélio de Almeida 75, 21941-906, Cidade Universitária, Ilha do Fundão, Rio de Janeiro-RJ, Brazil. \\ godoy_geo@yahoo.com.br
}

*CORRESPONDING AUTHOR, renatacouraborges@hotmail.com

Received on 9 April 2016

Received in revised form on 10 Jun 2016

Accepted on 11 Jun 2016

Editor:

Maria Virginia Alves Martins, Universidade do Estado do Rio de Janeiro, Brazil

\section{Abstract}

As well as other sub-basins of the Guanabara Bay, the Canal do Cunha watershed, located in the Rio de Janeiro city, has suffered severe environmental degradation since the 50 s, due to accelerated urban-industrial development. The fluvial dynamics has changed by the deforestation, landfill constructions, drainage and vale occupation. Canal do Cunha deliver wastewaters and sediments at the western side of Guanabara Bay. Contribute to the environmental degradation and has direct influence on the water quality indexes and heavy metal contamination at the western side of Guanabara Bay. This study intends to evaluate, through geoprocessing techniques, the spatial distribution of Lead $(\mathrm{Pb})$, Zinc ( $\mathrm{Zn})$, dissolved oxygen (DO) and total phosphorus (total $\mathrm{P}$ ) concentrations and $\mathrm{pH}$ values, using data provided by six monitoring stations of the Instituto Estadual do Ambiente - INEA (State Environmental

\section{Introduction}

The waterways of metropolitan areas in various parts of the world, such as areas in which a vast contribution of domestic and industrial effluents causes degradation of these waterways are impacted by various anthropic activities.
Citation:

Borges, R.C., Caldas, V.G., 2016. A Review of Use of GIS for the Evaluation of Heavy Metal and Water Quality Parameters in the Canal do Cunha Watershed and west of the Guanabara Bay, Rio de Janeiro (Brazil). Journal of Sedimentary Environments, 1(2): 268-278.

Institute). This work allows to observe the influence of weather conditions on $\mathrm{Pb}$ and $\mathrm{Zn}$ concentrations in superficial waters and surface sediments and the behavior of $\mathrm{DO}, \mathrm{pH}$ and total $\mathrm{P}$ of superficial waters before and after the implementation of the remediation program: Programa de Despoluição da Baía de Guanabara (PDBG; Pollution Remediation Program of Guanabara Bay). Canal do Cunha flow has direct influence on the low quality indexes of water and contributes to the heavy metal contamination and environmental degradation of the western region of Guanabara Bay.

Keywords: Water contamination. Sediments contamination. Metals. Quality parameters. GIS.

The contamination of aquatic ecosystems by heavy metals is of great importance due to the negative effects on trophic chains, with a direct and immediate influence on human health (Cowen and Silver, 1984). 
Remediation process remains challenging due to the lack of knowledge on the behavior of metals in aquatic ecosystems (Warren and Haak, 2001). According to Warren and Haak (2001), metals can exist in various forms in water; however, all metals are not equally toxic, mobile or bioavailable. Metal associations are dynamic, reversible and reflect physicochemical changes in the water. Consequently, potential effects from metals released from sediment exist even with reduced amounts of metals (Fonseca et. al., 2013).

The degradation in water quality can be caused by a result of human made pressure as well as natural factors which are mostly accelerated by human activities (rock and soil erosion).

However, the watercourses of the metropolitan area have suffered, heavily, with many human activities (with the contribution of domestic and industrial effluents) established in their proximity. According to Pesquisa Anual de Amostras de Domicílio (PNAD; Annual Survey of Household Sample of 2009) $72.7 \%$ of the households were provided by the state's sewerage network (IBGE, 2010). In 2011 , the coverage data presented the result of 70\% (IBGE, 2012), showing a raise in household numbers and, consequently, an aggravation in environmental pollution due to the raise of untreated waste. The effluents which most affect the water resources are the organic components, heavy metals and nutrients which come from domestic and industrial waste.

Lead $(\mathrm{Pb})$ and zinc $(\mathrm{Zn})$ even though they are essential for some of modern society activities, they can harm health and provoke stress in coastal ecosystems (Rocha et al., 2010). Lead has as a main source the urban superficial outflow contribution, associated to the additives of automotive fuels.

Zinc is supplied from many kind of industries, such as: metallurgical, electroplating, painting, insecticide, pharmaceutical, luminescent products and fibril. It can even come from mining wastes and untreated domestic effluents (Martin et al., 1976).

The lack of criteria to measure the superficial contamination in the sediments and in superficial waters led Conselho Nacional do Meio Ambiente (CONAMA) to establish the Sediment Quality Value Guide (VGQS), with the resolution $344 / 2004$, and in water, with the resolution 357/2005.

This work used an interpolation technique aiming to evaluate - the pollution degree by heavy metals and to determine some quality parameters from water around the Canal do Cunha watershed and west of the Guanabara Bay.

\section{Material and methods}

According to INEA (2003), the Canal do Cunha watershed (Fig. 1) is situated in Rio de Janeiro State (between the latitudes $22^{\circ} 51^{\prime}$ and $22^{\circ} 55^{\prime} \mathrm{S}$ and the longitudes $43^{\circ} 15^{\prime}$ and $43^{\circ} 20^{\prime} \mathrm{W}$ ). It has $84^{\circ} \%$ of its area (approximately 62.85 $\mathrm{km}^{2}$ ) in a densely urbanized area, including slums, clandestine or irregular allotment. The only existent natural area is the Tijuca Park which has secondary forests in good shape. Faria river mouth is located at the west region of Guanabara Bay, next Fundão Island (University city; Fig. 1B).

The metal distribution in water and on sediment, discussion and the water quality parameters in Canal do Cunha and in the west part of the Guanabara Bay is grounded on data provided by the Instituto Estadual do Ambiente (INEA; State Environmental Institute). Since the 70 s the Fundação Estadual de Engenharia do Meio Ambiente (FEEMA; State Foundation of Environmental Engineering) monitored the main water bodies of the Rio de Janeiro state, providing historical series which allows the analysis of the evolution of environmental conditions of the fluvial ecosystem of this study.

Data of six monitoring stations were selected to be analysed in this work (Fig. 2): CN100, FR142, GN22, GN43, GN48 and GN50. In the station GN43 were not recorded sedimentological data.

Data of surface water were obtained by collecting samples with a Van Dorn bottle, stored in $500 \mathrm{~mL}$ polyethylene bottles, cooled at $4^{\circ} \mathrm{C}$ and protected from light, for further filtration (INEA, 2003).

Sediments were recovered with a Van Veen grab. Sediment samples were stored on sanitized flasks. A Styrofoam cooler with ice was used to store and to transport these samples. The samples were sent to TASQA-Serviços Analíticos, Ltda. in Campinas, São Paulo, to perform the stages of openness of samples and analysis of extracts by inductively coupled plasma-optical emission spectrometry (ICP-OES).

The digestion of the sediment samples $(0.5 \mathrm{~g})$ for the metal analysis was performed according to EPA method 3051, using $\mathrm{HCl}$ and $\mathrm{HNO}_{3}, 3: 1$, respectively (EPA, 2007). The digestion was performed in a microwave oven. After the digestion, the liquid phase was filtered and transferred to polyethylene tubes. The obtained solution was subsequently diluted with deionized water to $20 \mathrm{ml}$. The analysis was performed using ICP-OES.

The water quality parameters were determined using the methodology described in Borges et al. (2015). 

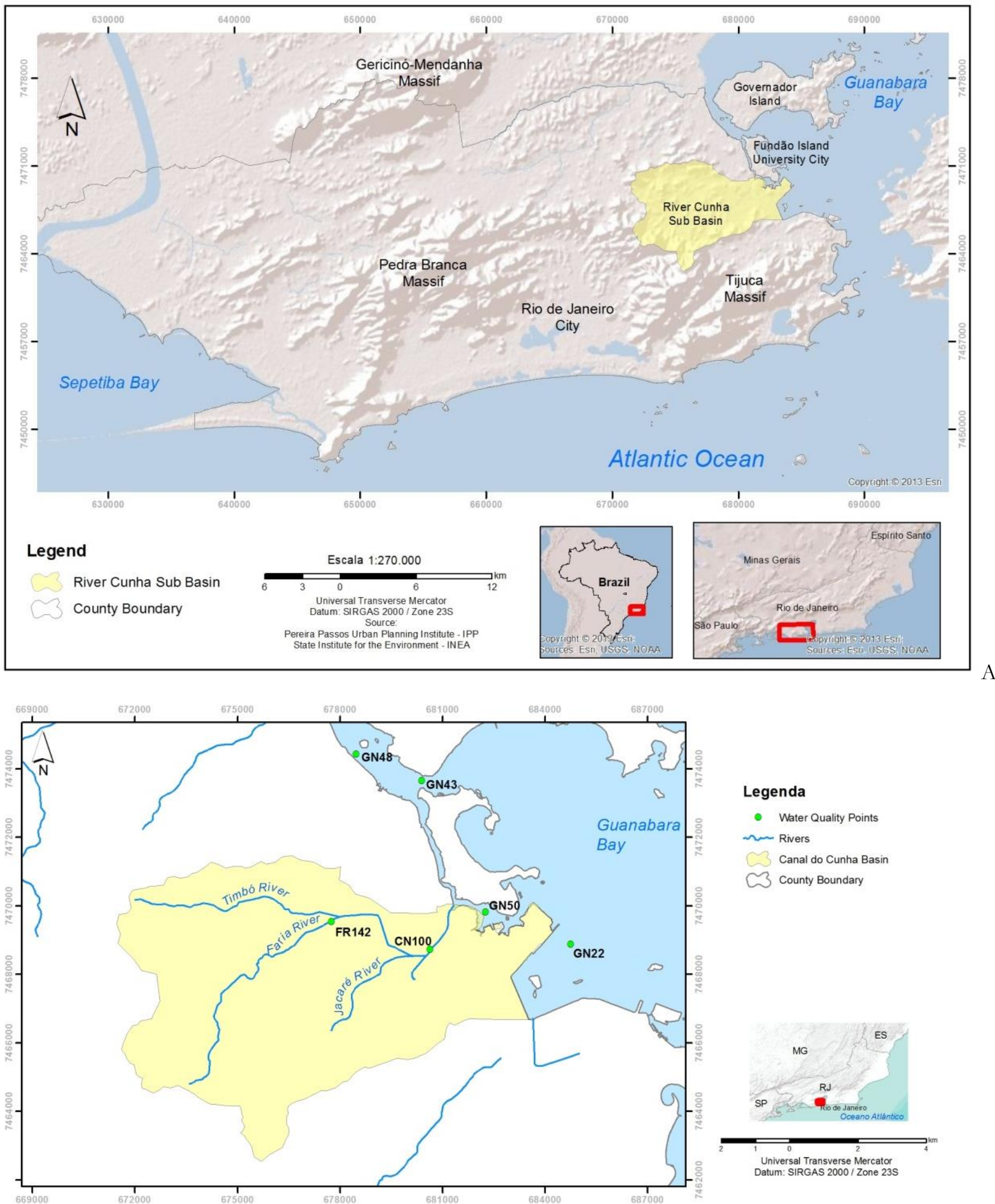

Fig. 1. (A) Canal do Cunha watershed. (B) Location of collection points in the river Canal Cunha Basin and west of Guanabara Bay. 
Once georeferenced according to its coordinates in the sampling stations of INEA, these data were converted in vector format of points and interpolated with the technique Inverse Distance Weighted (IDW), available in the ArcGIS 10 software (ESRI, 2011). The mathematical method used by the interpolator IDW is represented on equation 1, were: $\mathrm{z}=$ interpolated value; $\mathrm{n}=$ number of observed individuals; $\mathrm{zi}=$ values attributed to the observed individuals; $\mathrm{di}=$ distance between the observed and interpolated individuals (Varella and Junior, 2008):

$$
x=\frac{\sum_{i=1}^{n} \frac{1}{d_{i}^{p}} z_{i}}{\sum_{\mathrm{i}=1}^{\mathrm{n}} \frac{1}{\mathrm{~d}_{\mathrm{i}}^{\mathrm{p}}}}
$$

The criteria to choose this method was given by its properties. It does not estimate values higher or lower than the maximum and minimum recorded in the sampling points, which does not happen in methods such as Kernel.

The used basemap was provided by the Department of Geosciences at UFRJ, Cartography Laboratory (Geocart), as a result of the project "Implementation of information network for the environmental management of the Guanabara Bay basin, based on geographic information system - GIS" developed for the Instituto Brasileiro de Administração Municipal (IBAM; Brazilian Institute of Municipal Administration) and for Instituto Brasileiro de Meio Ambiente e Recursos Naturais Renováveis (IBAMA, 2002; Brazilian Institute of Environment and Renewable Natural Resources). This consisted of an edition of a mosaic of sheets 1:50.000 from IBGE and Diretoria de Serviço Geográfico (DSG; Direction of Geographic Service). Among the plans of information developed by the project, only the data related to hydrography and coastline was adopted.

(A) 1998 - 2003

(B) 2004 - 2011
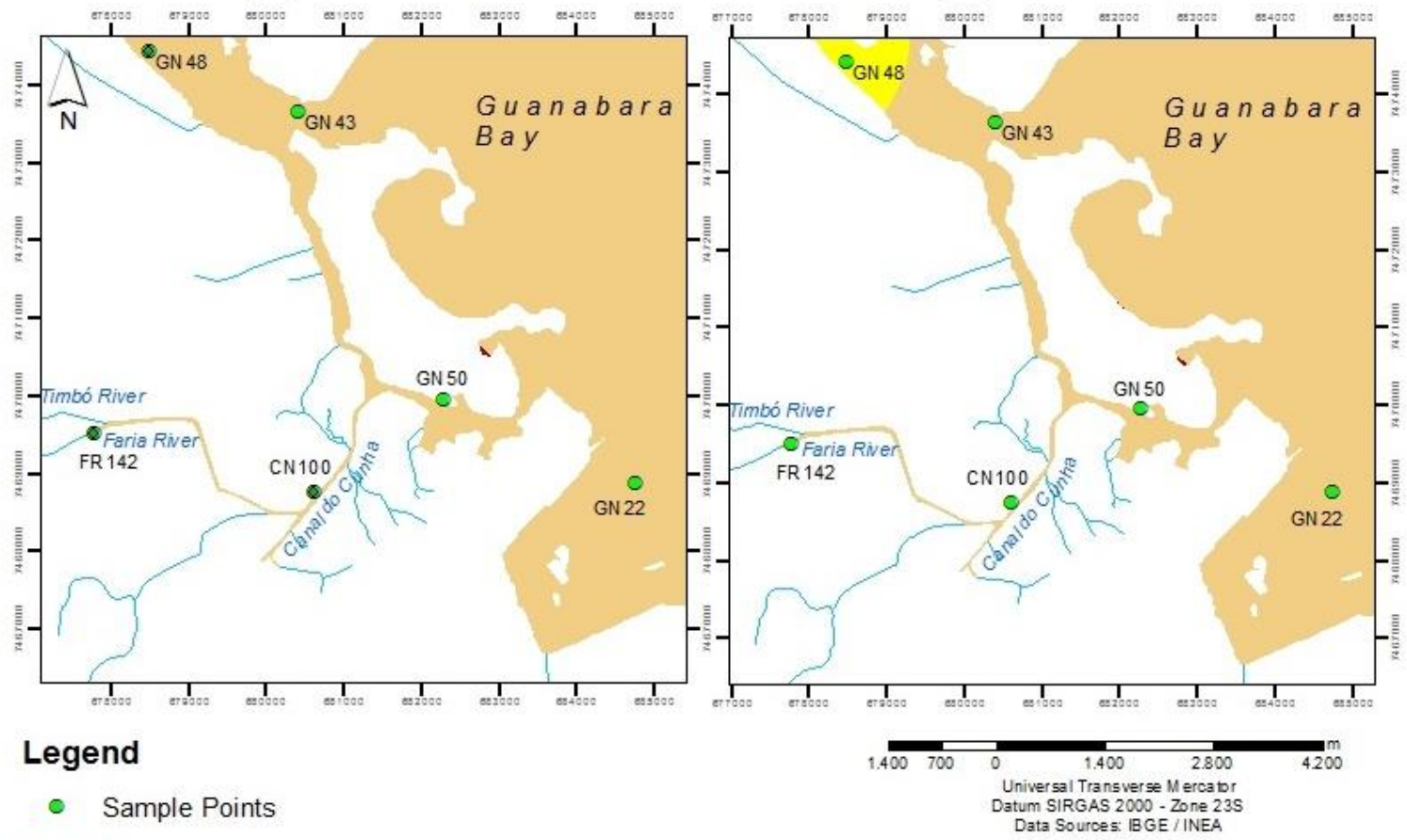

Legend

- Sample Points

num - Rivers

\section{pH - Brackish Water}

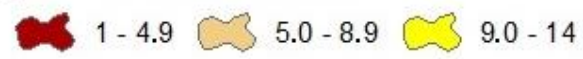

Fig. 2. Distribution of the pH values before and after the PDBG (Programa de Despoluição da Baía de Guanabara. 
Considering the complexity and high variability normally observed in environmental studies (Einax and Soldt, 1999), it is frequent in these types of studies to use multivariate statistical methods to identify and differentiate natural levels of heavy metals from anthropogenic contamination.

In order to verify the parameters that contribute the most to such a characterization and how they are related to the methods used, cluster analysis was performed using the software STATISTICA 7 (Copyright1984-1987, Stat- Soft, Inc. 2300 East 14th Street Tulsa, OK 74104, USA).

\section{Results}

Table 1 shows the results of water quality parameters in two time periods before (1998-2003) and after (2004-2011) the PDBG. These results represent the average concentrations of monthly values for each station, which were subsequently grouped in years and finally transformed in the periods used in this work.

The $\mathrm{pH}$ values varied between $6.72-9.24$, though not vary greatly in both time periods, except in GN48. The lowest $\mathrm{pH}$ values was found in the FR142 point in Faria River. The highest $\mathrm{pH}$ value was obtained in GN48 point in the Guanabara Bay.

The DO values vary between $0.23-7.84 \mathrm{mg} \mathrm{L}^{-1}$. The DO concentrations are critical in CN100 and FR142 and below the minimum required to maintain aquatic life $\left(4 \mathrm{mg} \mathrm{L}^{-1}\right.$, according to CONAMA, 2005). GN43 and GN50 points located in Guanabara Bay, are also below the minimum set by CONAMA (2005) for saline water $6 \mathrm{mg} \mathrm{L}^{-1}$. Regular concentrations are found in GN22 on both periods.

Tab. 1. Average concentrations of monthly values for each station of Water Quality Parameters for the periods 1998-2003 and 20042011. DO - dissolved oxygen.

\begin{tabular}{|c|c|c|c|c|c|c|}
\hline Station & $\begin{array}{c}\text { DO } \\
(1998-2003) \\
\left(\mathrm{mg} \mathrm{L}^{-1}\right)\end{array}$ & $\begin{array}{c}\text { DO } \\
(2004-2011) \\
\left(\mathrm{mg} \mathrm{L}^{-1}\right)\end{array}$ & $\begin{array}{c}\text { Total P } \\
(1998-2003) \\
\left(\mathrm{mg} \mathrm{L}^{-1}\right)\end{array}$ & $\begin{array}{c}\text { Total P } \\
(2004-2011) \\
\left(\mathrm{mg} \mathrm{L}^{-1}\right)\end{array}$ & $\begin{array}{c}\text { pH } \\
(1998-2003)\end{array}$ & $\begin{array}{c}\text { pH } \\
(2004-2011)\end{array}$ \\
\hline CN100 & 0.23 & 0.35 & 1.93 & 1.81 & 6.90 & 6.88 \\
\hline FR142 & 0.96 & 0.80 & 1.90 & 4.95 & 6.88 & 6.72 \\
\hline GN22 & 6.99 & 7.84 & 0.18 & 0.21 & 8.27 & 8.03 \\
\hline GN48 & 6.06 & 6.14 & 0.51 & 0.69 & 7.61 & 9.24 \\
\hline GN50 & 4.16 & 4.17 & 0.98 & 0.76 & 7.41 & 7.55 \\
\hline GN43 & 3.92 & 5.88 & 0.44 & 0.48 & 7.93 & 7.84 \\
\hline
\end{tabular}

The values of total $\mathrm{P}$ vary between $0.18-4.95 \mathrm{mg} \mathrm{L}^{-1}$. The total $\mathrm{P}$ levels were above $0.186 \mathrm{mg} \mathrm{L}^{-1}$ in all the analyzed points. This is considered the maximum limit permitted by CONAMA (2005).
Table 2 shows the concentrations of heavy metals in water and sediment. The $\mathrm{Pb}$ concentrations in the sediments are much higher than in water, regardless of the evaluated period, dry or rainy season.

Tab. 2. Average concentrations of monthly values for each station of concentrations of heavy metals in water and sediment. Legend: RS - Rainy Season; DS - Dry Season

\begin{tabular}{|c|c|c|c|c|c|c|}
\hline Station & $\begin{array}{c}\mathbf{P b}-\text { water } \\
\text { RS } \\
\left(\mathrm{mg} \mathrm{kg}^{-1}\right)\end{array}$ & $\begin{array}{c}\mathbf{P b}-\text { water } \\
\mathbf{D S} \\
\left(\mathrm{mg} \mathrm{kg}^{-1}\right)\end{array}$ & $\begin{array}{c}\mathbf{P b}- \\
\text { sediment } \\
\left(\mathrm{mg} \mathrm{kg}^{-1}\right)\end{array}$ & $\begin{array}{c}\mathbf{Z n - w a t e r} \\
\mathbf{R S} \\
\left(\mathrm{mg} \mathrm{kg}^{-1}\right)\end{array}$ & $\begin{array}{c}\mathbf{Z n - w a t e r} \\
\mathbf{D S} \\
\left(\mathrm{mg} \mathrm{kg}^{-1}\right)\end{array}$ & $\begin{array}{c}\mathbf{Z n ~ - ~} \\
\text { sediment } \\
\left(\mathrm{mg} \mathrm{kg}^{-1}\right)\end{array}$ \\
\hline CN100 & 0.04000 & 0.0300 & 21 & 0.00013 & 0.00005 & 20111 \\
\hline FR142 & 0.01625 & 0.0100 & 10 & 0.00004 & 0.00005 & 37 \\
\hline GN22 & 0.01150 & 0.0051 & 60 & 0.03480 & 0.02252 & 174 \\
\hline GN48 & 0.00607 & 0.0050 & 50 & 0.01225 & 0.02647 & 250 \\
\hline GN50 & 0.00555 & 0.0050 & 70 & 0.01200 & 0.03491 & 270 \\
\hline
\end{tabular}


Lead concentrations vary between $0.0055-0.0400 \mathrm{mg} \mathrm{L}^{-1}$ and between $0.0050-0.0300 \mathrm{mg} \mathrm{L}^{-1}$ in water, during the rainy and dry seasons respectively. Lead concentrations vary between 10-70 mg L-1 in the sediment. Zinc concentrations, on the other hand, had a homogeneous variation in the

\section{Discussion}

The $\mathrm{pH}$ directly influences the mobility, precipitation and adsorption of heavy metals in acidic environments. The tendency of metals is to be soluble in the water column (Warren and Haak, 2001); however alkaline environments promote precipitation and adsorption of these elements (Warren and Haak, 2001).

Fig. 3 shows the distribution of $\mathrm{pH}$ before and after the remediation works of Guanabara Bay. The $\mathrm{pH}$ values do not change much from one period to another. The lowest value was observed in point FR124 (6.2). evaluated stations. Zinc concentrations ranged from $0.00004-0.0348 \mathrm{mg} \mathrm{L}^{-1}$ in the rainy season. In the dry period, Zn concentrations varied between $0.00005-0.03491 \mathrm{mg} \mathrm{L}^{-1}$. However the sediment present a wide variation (between 37 $20111 \mathrm{mg} \mathrm{kg}^{-1}$ ) of $\mathrm{Zn}$ content.
(A) 1998 - 2003

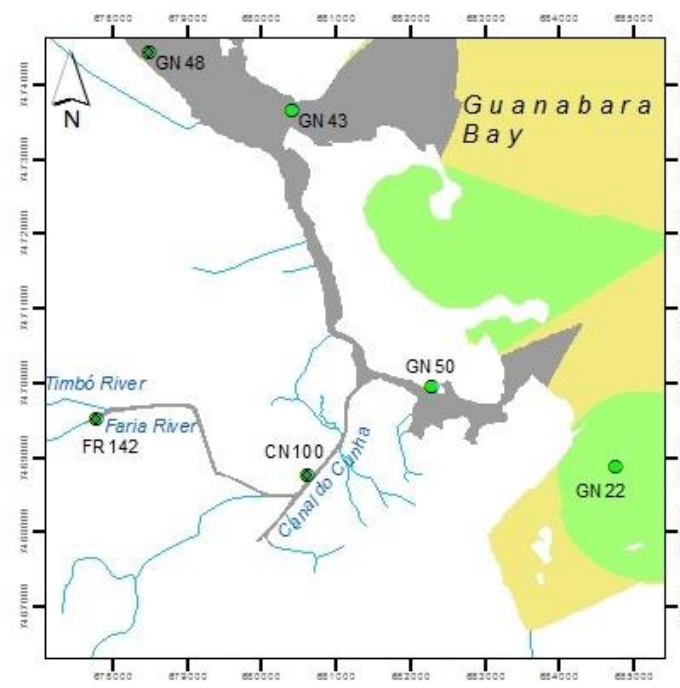

Legend

- Sample Points

nom- Rivers
This low value is not relevant because, according to Resolution 357 of CONAMA (2005), the $\mathrm{pH}$ of fresh water can range from 6-9. The largest $\mathrm{pH}$ value in GN48 point exceeds the allowed limit for saline water (between 6.5 and 8.5).

These values are influenced by human activities. It can be stated that these values are mostly neutral or alkaline. Under these conditions the metals are probably precipitated or adsorbed in the sediments.

\section{Dissolved Oxygen ( $\mathrm{mg} / \mathrm{L})$}

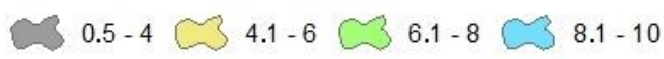

Fig. 3. Variation in concentration of dissolved oxygen in two periods before and after the PDBG. 
Regarding water quality parameters, DO concentrations were in critical condition (Fig. 4), that is far from the below levels of $4 \mathrm{mg} \mathrm{L}^{-1}$, the minimum values established by resolution 357 of CONAMA (CONAMA, 2005) for maintenance of aquatic life. The lowest values occurred at CN100 and FR142 stations, with 0.55 and $0.80 \mathrm{mg} \mathrm{L}^{-1}$, respectively. The stations located in Guanabara Bay were also critical, with the exception of GN22 which was within the standards. These results indicate that the works promoted by the PDBG acted positively in this parameter, contributing to improving water quality in the Guanabara Bay. However the water quality in the Canal do Cunha watershed remained critical.
For total P (Fig. 5) the maximum limit established by the resolution 357 of CONAMA (CONAMA, 2005) is $0.186 \mathrm{mg}$ $\mathrm{L}^{-1}$. In the evaluated area before sanitation projects promoted by the PDBG the total P concentrations exceeded the limit on all points except in GN22. This fact can be associated with the water circulation in Guanabara Bay where the water is more quickly renewed. In the second period there was a worsening of total $\mathrm{P}$ levels and this may be occurring due to the increase in population on the slums of the region. In addition, even with the structuring of sewage networks in these slums, these are still released of untreated wastewater into rivers and streams of Canal do Cunha watershed.
(A) 1998 - 2003

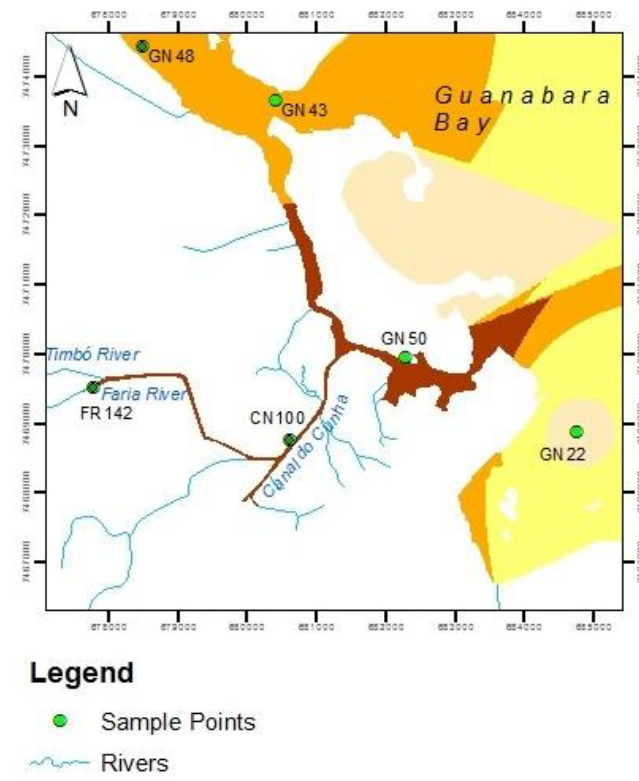

(B) 2004 - 2011

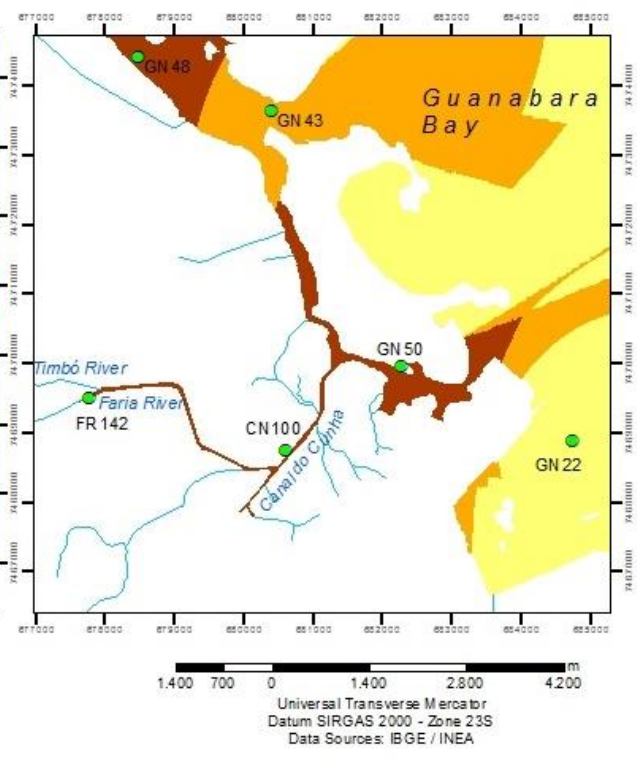

Total Phosphorus ( $\mathrm{mg} / \mathrm{L}$ )

@ 0.09-0.186 $0.187-0372 \bigcirc 0.373-0.558 \backsim 0.559-5$

Fig. 4. Variation on P total concentration on periods before and after PDBG.

The distribution of $\mathrm{Pb}$, Fig. 6, indicates that the concentrations of this element in surface water were higher during the rainy season compared to the dry season. These data suggest that urban shallow continental runoff is a major source of $\mathrm{Pb}$ and the rains potentiate their discharge on rivers of the Canal do Cunha watershed and consequently in Guanabara Bay. The sampling stations located on the Canal do Cunha watershed and Faria river have the highest $\mathrm{Pb}$ concentrations in water compared with the stations of Guanabara Bay. This is due to dilution caused by circulation and hydrodynamics in Guanabara Bay. However, all $\mathrm{Pb}$ concentrations in surface waters are below the maximum extent permitted by the resolution 357 of CONAMA (CONAMA, 2005).

The concentration of $\mathrm{Pb}$ in sediments was much higher than that found in surface waters; this fact is probably associated with the adsorption of this metal by organic matter and fine sedimentary particles, which is facilitated in alkaline environments. However, $\mathrm{Pb}$ concentrations in sediments did not exceed the limit established by resolution 344 of CONAMA (CONAMA, 2004). 
Rainy Season

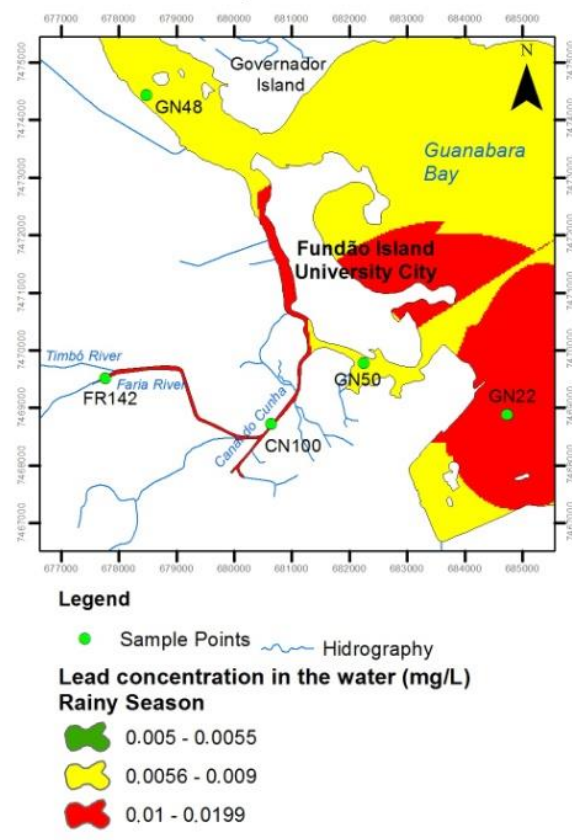

Dry Season

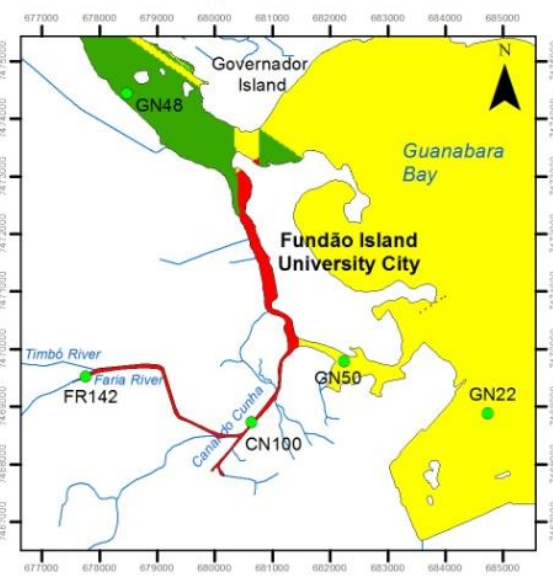

Lead concentration in the water $(\mathrm{mg} / \mathrm{L})$ Dry Season

$0.0049-0.005$

C $0.0051-0.009$

$0.01-0.0299$

\section{Sediment}

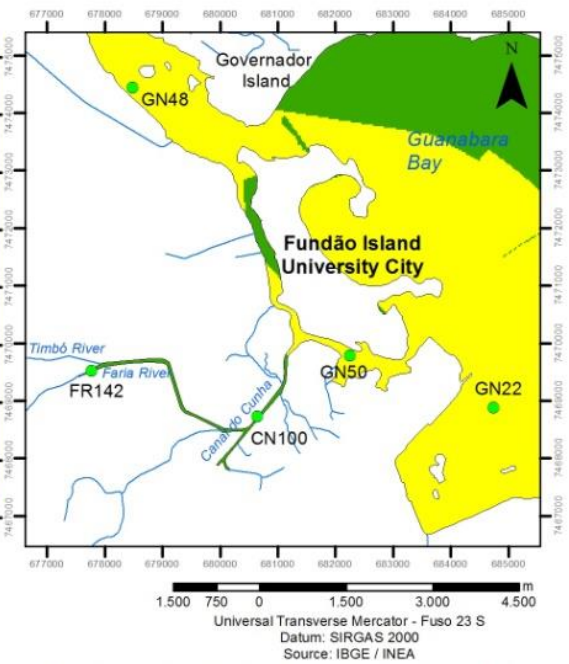

Lead concentration in the sediment $(\mathrm{mg} / \mathrm{Kg})$

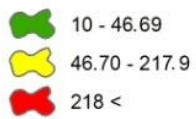

Fig. 5. Maps of distribution of $\mathrm{Pb}$ concentrations in water and sediment.

Rainy Season

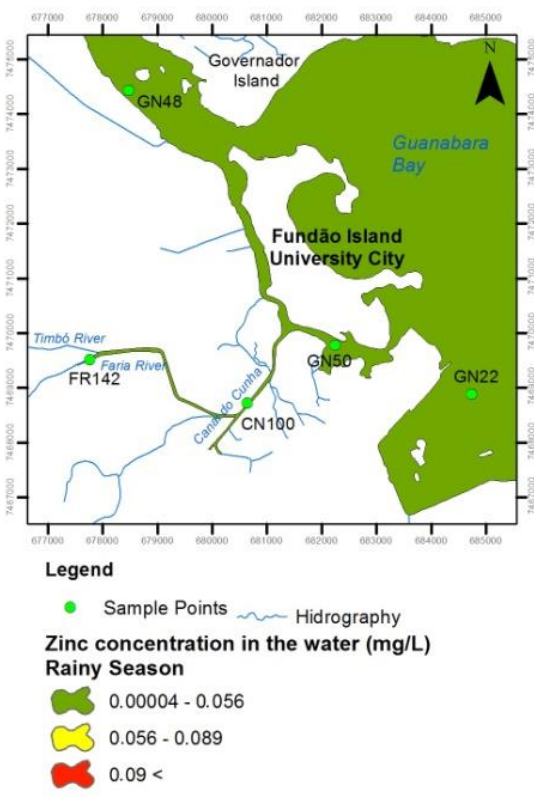

Dry Season

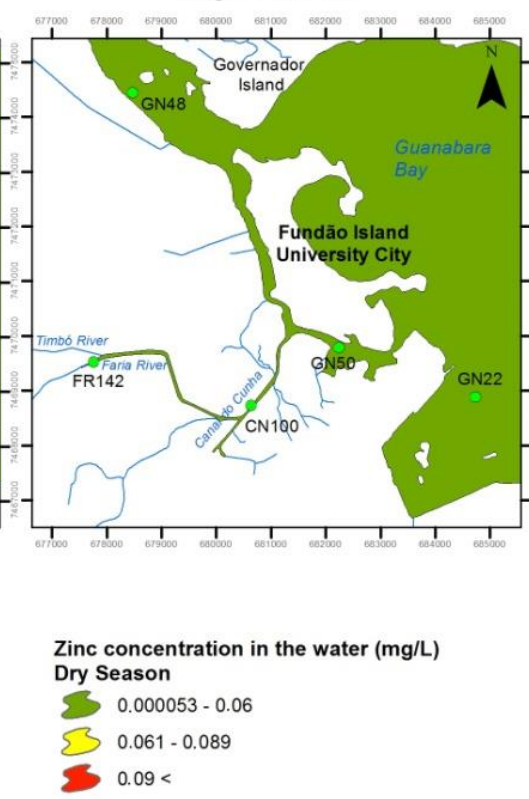

\section{Sediment}

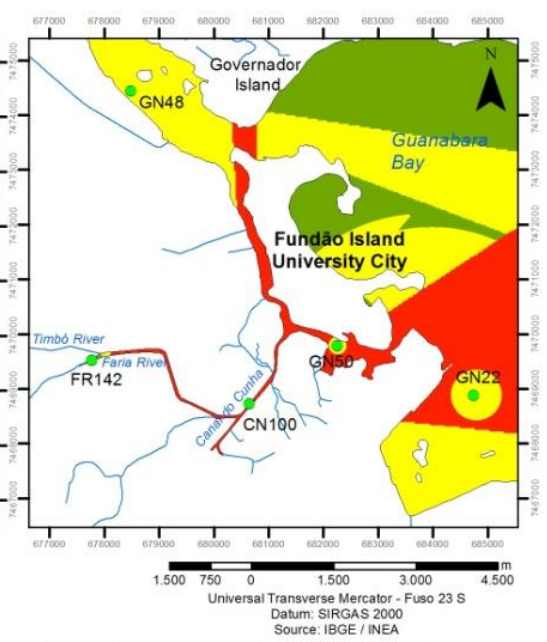

Zinc concentration in the sediment $(\mathrm{mg} / \mathrm{Kg})$

$10.008-150.9$

$150-409.9$

$410<$

Fig. 6. Variation in $\mathrm{Zn}$ concentration in water and in sediment. 
Hatje et al. (2001) studying Port Jackson in Australia found a $\mathrm{Pb}$ range between 110 and $240 \mathrm{mg} \cdot \mathrm{kg}^{-1}$ in sediment. Regnier and Wallast (1993) studying the Scheldt Estuary in northern France, Germany and Netherlands found $\mathrm{Pb}$ concentrations of about $185 \mathrm{mg} \cdot \mathrm{kg}^{-1}$ in sediment. The values presented in these works are above that obtained in the study area.

The seasonal variation of $\mathrm{Zn}$ concentration in surface water (Fig. 7), showed no significant differences between the rainy and the dry season. This fact shows that $\mathrm{Zn}$ is not from the urban continental runoff, but is supplied by several industries operating in the region, so the rains do not interfere with their distribution. In addition, $\mathrm{Zn}$ values in water were below the maximum limit permitted by resolution 357 of CONAMA (CONAMA, 2005).

The $\mathrm{Zn}$ concentrations in the sediment was much higher than in water, probably due to the alkaline environment favoring its adsorption. However, the concentration of this element in the sediment exceeded the maximum limit established by resolution 344 of CONAMA (CONAMA, 2004), indicating that this metal may be a risk to the environment of Guanabara Bay.

The $\mathrm{Zn}$ concentrations in the station $\mathrm{CN} 100$, located in the outer sector of the Canal do Cunha (20111 mg kg-1) are much higher than those reported in the international

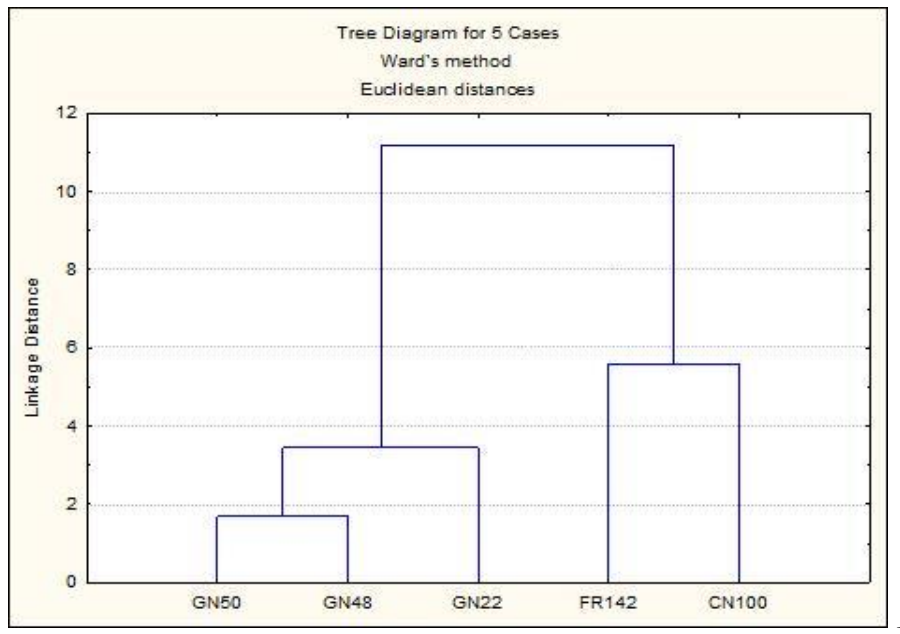

literature. Hatje et al. (2001) studying the sediments of Port Jackson Australia found Zn concentrations between 400 and $800 \mathrm{mg} \mathrm{kg}^{-1}$. Stecko et al. (2000) studying Fraser Estuary River (Canada) obtained $\mathrm{Zn}$ values between 50 and $700 \mathrm{mg}$ $\mathrm{kg}^{-1}$ in the sediment.

Figure 7 shows the statistical analysis of the distribution of heavy metals and water quality parameters, respectively. The results are similar in both analysis (the same groups of stations are recognized) for the studied sets of variables. Occurs the formation of two large groups of stations. The first formed by the stations located on the watershed of the Canal do Cunha. These stations are experiencing the highest level of contamination for both analyzed metals and for the water quality parameters. This fact is directly associated with the local hydrological characteristics, where the channeling of rivers contributed to the silting and, consequently, to a poor circulation and a highest concentration of metals and total P.

The second large group established by cluster analysis is formed by the stations located on the western side of Guanabara Bay. There is a greater similarity between the GN50, GN48 and GN43, probably due to hydrological conditions, as they are stations where there is a poor water circulation. The GN22 station displayed a more differentiated behavior since it is less affected both by metal contamination and for low quality water.

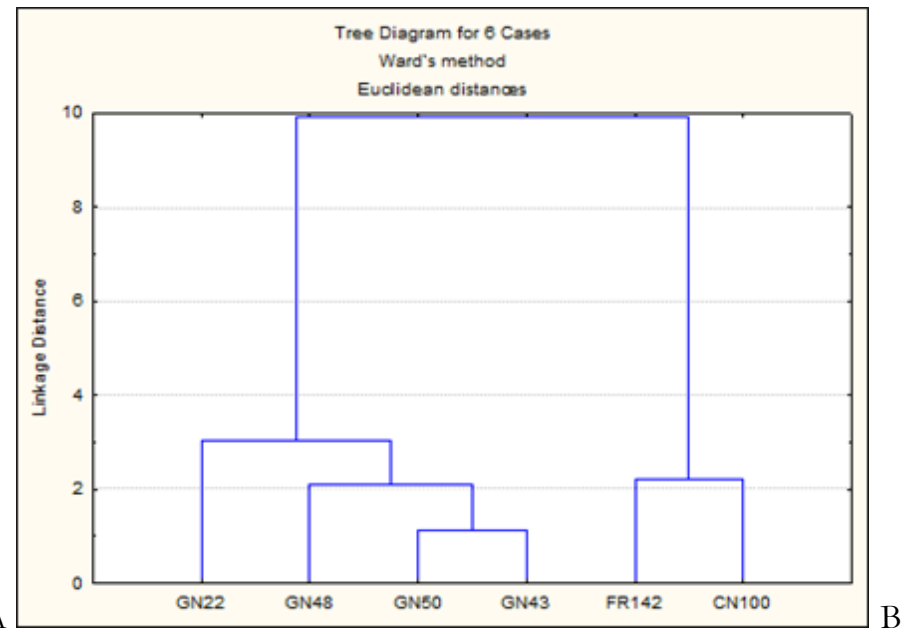

Fig. 7. Cluster analysis. (A) Dendrogram of stations evaluated for heavy metals. (B) Dendrogram of stations evaluated for water quality parameters. 


\section{Conclusion}

In the study area, the $\mathrm{pH}$ varied in an alkaline range in most of the sites, in both analyzed periods, which favors precipitation and adsorption of metals.

The concentrations of $\mathrm{Pb}$ and $\mathrm{Zn}$ in surface water are substantially lower than the concentrations of these elements in the sediment. The deposition of great amount of organic matter and fine grained particles in the Canal do Cunha watershed and the western side of Guanabara Bay should promote the adsorption of metals.

The results indicate that the amount of $\mathrm{Pb}$ reaching the Canal do Cunha watershed and the western part of Guanabara Bay exponentially increase during the rainy season. The $\mathrm{Zn}$ concentrations in sediment exceeded the maximum extent permitted by resolution 344 of CONAMA.

According to the water quality parameters, the Canal do Cunha watershed can be classified as Class 4 , in other words, the water is so altered and degraded that only can be used for navigation and landscape harmony, according to CONAMA Resolution No. 357/05.

Even after the works of sanitation held in the slums of the watershed Canal do Cunha through the Favela-Bairro Project, the improvement on water quality was not observed. This fact is due to an increase in population in these slums and also even after the construction of sewage networks, there was no treatment of this sewage before being released into rivers and streams of the region.

\section{Acknowledgments}

The authors would like to acknowledge the Conselho Nacional de Desenvolvimento Científico e Tecnológico (CNPq) and Coordenação de Aperfeiçoamento de Pessoal de Nível Superior (CAPES) for the fellowship and financial support.

\section{References}

Borges, R.C., Santos, F. V., Caldas, V.G., Lapa, C.M.F., 2015. Use of geographic information system (GIS) in the characterization of the Cunha Canal, Rio de Janeiro, Brazil: effects of the urbanization on water quality. Environmental Earth Science 73, 1345-1356. doi: 10.1007/s12665-014-3493-1

Conselho Nacional de Meio Ambiente - CONAMA (2004). Resolução CONAMA n 344, de 25 de maio de 2004. Brasília. Available: http://www.saneago.com.br/novasan/leis/conama.pdf.

Conselho Nacional de Meio Ambiente - CONAMA (2005). Resolução CONAMA n 357, de 17 de março de 2005. Brasília. Available: http://www.saneago.com.br/novasan/leis/conama.pdf.
Cowen, J.P., Silver, M.W., 1984. The association of iron and manganese with bacteria on marine macroparticulate material. Science 224, 1340-1342.

Einax, J.W., Soldt, U., 1999. Geostatistical and multivariate statistical methods for the assessment of polluted soils - merits and limitations. Chemometrics and Intelligent Laboratory Systems 46, 79-91. doi:10.1016/S0169-7439(98)00152-X

Environmental Protection Agency - EPA, 2007. Microwave assisted acid digestion of sediments sludge, soils, and oils. EPA 3051. 30p). Available in: http://www.epa.gov/epawaste/hazard/testmethods/sw846/ pdfs/3051a.pdf

Environmental Systems Research Institute - ESRI (2011). Desktop Help 10.0 - How IDW works. Available: http://help.arcgis.com/en/arcgisdesktop/10.0/help/index.ht ml\#/How_IDW_works/009z0 000075000000/

Fonseca, E.M., Baptista Neto, J.A., Silva, C.G., McAlister, J.J., Smith, B.J., Fernandez, M.A., 2013. Stormwater impact in Guanabara Bay (Rio de Janeiro): Evidences of seasonal variability in the dynamic of the sediment heavy metals. Estuarine, Coastal and Shelf Science 130, 161-168. doi:10.1016/j.ecss.2013.04.022

Grasshoff, K., Ehrhardt, M., Kremling, L., 1983. Methods of Seawater Analysis. 2nd, Verlag Chemie, Weinheim.

Hatje, V., Birch, G.F., Hill, D.M., 2001. Spatial and Temporal Variability of Particulate Trace Metals in Port Jackson Estuary, Australia. Estuarine, Coastal and Shelf Science 53, 63-77. doi:10.1006/ecss.2001.0792

Instituto Brasileiro de Administração Municipal - IBAM/ Instituto Brasileiro do Meio Ambiente e dos Recursos Naturais Renováveis - IBAMA (2002). Implantação da rede de informações para a gestão ambiental da bacia da Baía de Guanabara, com base em sistema de informações geográficas SIG. Available: < http://www.ibama.gov.br

Instituto Brasileiro de Geografia e Estatística - IBGE, 2010. Pesquisa Nacional por Amostras de Domicílios. Síntese de Indicadores 2009. Available in: http://www.ibge.gov.br/home/estatistica/populacao/trabalh oerendimento/pnad2009/pna d_sintese_2009.pdf.

Instituto Brasileiro de Geografia e Estatística - IBGE (2012). Pesquisa Nacional por Amostras de Domicílios. Síntese de Indicadores 2011. Available in: ftp://ftp.ibge.gov.br/Trabalho_e_Rendimento/Pesquisa_Na cional_por_Amostra_de_Domicilios_anual/2011/Sintese_In dicadores/sintese_pnad2011.pdf .

Instituto Estadual do Ambiente - INEA (2003). Plano diretor de recursos hídricos da região hidrográfica da Baía de Guanabara. Rio de Janeiro. 2003. Available in: http://www.inea.rj.gov.br/recursos/downloads/comite_baia _guanabara_plano_bacia_vol

Martin, J.M., Meybek, M., Salvador, F., Thomas, A., 1976. Pollution chimique des estuaries: état des connaissances. Centre National pour I'Explotation dês Oceans. Série Report Scientifiques ET p. 283. 
Regnier, P., Wollast, R., 1993. Distribution of trace metals in suspended matter of the Scheldt Estuary. Marine Chemistry 43, 3-19. doi:10.1016/0304-4203(93)90212-7

Rocha, D.S., Cunha, B.C.A., Geraldes, M.C., Pereira, S.D., Almeida, A.C.M., 2010. Metais pesados em sedimentos da baía de Sepetiba, RJ: implicações sobre fontes e dinâmica da distribuição pelas correntes de maré. Geochimica Brasiliensis 24, 63-70.

Stecko, J.R.P., Bendell-Young, L.I., 2000. Contrasting the geochemistry of suspended particulate matter and deposited sediments within an estuary. Applied Geochemistry 15, 695890. doi:10.1016/S0883-2927(99)00090-6

Strickland, J.D.H., Parsons, T.R., 1972. A practical handbook of seawater analysis. Bulletin (Fisheries Research Board of
Canada) 167, 2nd edn. Fisheries Research Board of Canada, Ottawa.

Varella, C.A.A., Junior, D.G.S., 2008. Estudo do Interpolador IDW do Arcview para Utilização em Agricultura de Precisão. Available: http://www.ufrrj.br/institutos/it/deng/varella/Downloads/I T190_principios_em_agricultra_de_precisao/Aulas/Estudo $\%$ 20do $\% 20$ interpolador $\% 20 \mathrm{idw} \% 20$ arcview.htm $>$.

Warren, L.A., Haach, E.A., 2001. Biogeochemical controls on metal behaviour in freshwater environmental. Earth-Science Reviews, 54, Issue 4, 261-320.

Winkler, L.W., 1888. Die Bestimmung des in Wasser gelösten Sauerstoffen. Berichte der Deutschen. Chemis chen Gesellschaft 21, 2843-2855. 